PRZEGLĄD BIBLIOTECZNY 2020 z. 3 PL ISSN 0033-202X

MAGDALENA WÓJCIK

Instytut Studiów Informacyjnych

Uniwersytet Jagielloński

e-mail: magda.wojcik@uj.edu.pl

ORCID: 0000-0001-5059-858X

\title{
LAPBOOK JAKO NARZĘDZIE PROMOCJI KSIĄŻKI DLA DZIECI
}

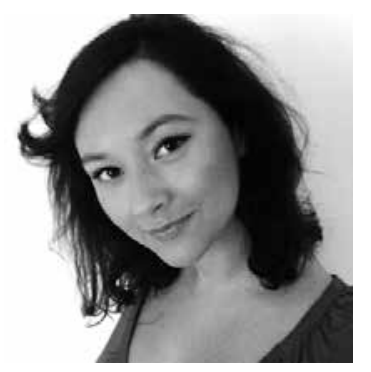

Dr hab. Magdalena Wójcik, adiunkt w Instytucie Studiów Informacyjnych Uniwersytetu Jagiellońskiego. Jej zainteresowania badawcze obejmuja problematykę wykorzystania najnowszych technologii informacyjno-komunikacyjnych w usługach instytucji książki. Najważniejsze publikacje to: Rozszerzona rzeczywistość w ustugach informacyjnych bibliotek (Kraków, 2018), Web 2.0 w działalności ustugowej instytucji ksiażki (Kraków, 2013), Internet of Things - potential for libraries, „Library Hi Tech" 2016, vol. 34, issue 2, pp. 404-420 oraz Holograms in libraries - the potential for education, promotion and services, „Library Hi Tech” 2018, vol. 36, issue 1, pp. 18-28.

SŁOWA KLUCZOWE: Biblioteki. Czytelnictwo. Innowacje. Lapbook. Promocja książki

ABSTRAKT: Teza/cel - Przedmiotem artykułu jest lapbook, analizowany jako forma promocji książki dla dzieci. Celem jest określenie potencjału tej formy pracy z użytkownikiem do wzmacniania procesów aktywizacji czytelniczej. Metoda - Zastosowano metodę analizy i krytyki piśmiennictwa. W oparciu o wyszukiwanie prowadzone w katalogu Biblioteki Narodowej i katalogu Worldcat, bazie abstraktowej LISTA oraz wybranych bazach wielodziedzinowych przeszukanych za pomocą narzędzia Google Scholar określono stan badań nad lapbookami. Pod uwagę wzięto wyłącznie prace opublikowane w języku polskim i angielskim w latach 2015-2019. Wyniki - Przeprowadzona analiza literatury przedmiotu po- 
zwala stwierdzić, że wykorzystanie lapbooków nie jest tematem często poruszanym w bibliotekoznawczej literaturze przedmiotu. Wnioski - Lapbook jest narzędziem stosowanym w praktyce bibliotekarskiej o dużym potencjalne dla promocji książki, brakuje jednak omówienia tego zjawiska w piśmiennictwie naukowym.

\section{WSTĘP}

Biblioteki stale poszukują nowych sposobów i narzędzi służących promocji książki i czytelnictwa. W przypadku działań kierowanych do dzieci i młodzieży często stosowaną strategią działania jest odwoływanie się do najnowszych technologii informacyjno-komunikacyjnych, co wydaje się naturalnym rozwiązaniem, biorąc pod uwagę popularność nowych technologii wśród tej grupy użytkowników. Badania przeprowadzone w 2017 r. wśród uczniów krakowskich szkół pokazały, że telefon komórkowy posiada już 95\% respondentów we wszystkich analizowanych przedziałach wiekowych, obejmujących uczniów od 6 do 19 roku życia, 86\% badanych respondentów regularnie korzysta z laptopa, a ponad połowa posiada w domu konsolę do gier (Instytut Badawczy IPC, 2017). Podobne badania prowadzone przez Fundację Dbam o Mój Z@sięg i Uniwersytet Gdański na grupie ponad 50 tys. młodych respondentów w całej Polsce pokazały, że już $97 \%$ badanych korzysta z telefonu komórkowego, niekiedy przez cały dzień, a ponad połowa z laptopów (Badanie Młodzi cyfrowi..., 2019). Biblioteki, podążając na nowymi trendami, wykorzystują w swojej działalności m.in. środowisko Internetu, media społecznościowe, technologie mobilne czy najnowsze narzędzia, takie jak choćby wirtualna czy rozszerzona rzeczywistość (Gmiterek \& Kotuła, 2017; Wójcik, 2018). W tym kontekście ciekawym i niestandardowym rozwiązaniem jest promowanie książki i czytelnictwa w sposób nawiązujący do kultury analogowej, poprzez tzw. lapbooki, specjalnie przygotowane teczki tematyczne zawierające elementy tekstu, a także rysunki, trójwymiarowe modele, zabawki, gry czy zagadki. Warto zastanowić się nad kontekstami używania lapbooków w bibliotekach i ich użytecznością dla procesów promocji książki dla dzieci.

\section{PRZEDMIOT, CEL, METODA}

Przedmiotem artykułu jest lapbook analizowany jako forma promocji literatury dla dzieci. Celem jest określenie potencjału tej formy pracy z użytkownikiem dla wzmacniania procesów aktywizacji czytelniczej. Do celów szczegółowych można zaliczyć:

- scharakteryzowanie koncepcji lapbooka i jego funkcji,

- omówienie cech lapbooków w kontekście rozwoju kultury DIY i personalizacji usług bibliotecznych, 
- omówienie edukacyjnych walorów lapbooków w kontekście koncepcji wzmocnień haptycznych,

- omówienie specyfiki lapbooków w kontekście trendów związanych z powrotem do kultury analogowej,

- określenie potencjału lapbooków jako formy wspierającej edukację czytelniczą i literacką dzieci.

Zastosowano metodę analizy i krytyki piśmiennictwa. W oparciu o wyszukiwanie prowadzone w katalogu Biblioteki Narodowej i katalogu Worldcat, bazie abstraktowej LISTA oraz wybranych bazach wielodziedzinowych przeszukanych za pomocą narzędzia Google Scholar określono stan badań nad koncepcją lapbooka. Pod uwagę wzięto wyłącznie prace opublikowane w języku polskim i angielskim w latach 2010-2019.

\section{STAN BADAŃ}

Wyszukiwanie przeprowadzone w wytypowanych źródłach informacji pokazało, że lapbook jest tematem rzadko podejmowanym w literaturze przedmiotu, szczególnie w piśmiennictwie polskim. Google Scholar indeksuje łącznie (na dzień 22.12.2019) 369 wyników, które zawierają słowo lapbook, jednak tylko w 17 pracach zagadnienie to pojawia się w tytule. Warto podkreślić, że nie wszystkie spośród 17 prac, w które lapbook jest głównym tematem rozważań, zostały opublikowane $\mathrm{w}$ języku polskim lub angielskim. Duża część z nich została opublikowana w języku hiszpańskim i rosyjskim. Wyszukiwanie w katalogu Worldcat przyniosło rezultat w postaci łącznie 112 prac z przyjętego okresu publikacyjnego, ale jedynie 45 prac spełniało przyjęte kryteria językowe, co więcej nie wszystkie publikacje były w pełni relewantne dla omawianego tematu (np. katalog Worldcat indeksuje obok publikacji o lapbookach, także konkretne pomoce dydaktyczne przygotowane $\mathrm{w}$ formie lapbooków). Najciekawszym z punktu widzenia celów tego artykułu tekstem anglojęzycznym okazała się publikacja: The lapbook as a didactic tool to implement integrated training in natural science and technology and entrepreneurship at primary school level (Peycheva \& Lazarova, 2018), artykuł omawiający zastosowanie lapbooków w edukacji. Na temat tworzenia lapbooków powstała również książka „Lapbooking Made Easy” (McGrew Jaime \& Fuller, 2013), niestety, nie jest ona dostępna w polskich bibliotekach ani online. Wyszukiwanie w bazie abstraktowej LISTA nie przyniosło żadnych relewantnych rezultatów, a wyszukiwanie w katalogu BN ujawniło jedną pracę dotyczącą lapbooków opublikowaną w języku polskim: Lapbook w bibliotece szkolnej : warsztaty artystyczne (Stącel, 2014). Artykuł Katarzyny Stącel jest pisany z perspektywy bibliotekarza-praktyka i dotyczy głównie aspektów technicznych i organizacyjnych związanych z organizacją 
warsztatów tworzenia lapbooków w bibliotece szkolnej. Niewielka objętość artykułu połączona z praktycznym profilem czasopisma, w którym został opublikowany nie pozwoliła autorce na poruszenie istotnych aspektów teoretycznych i tekst, choć bardzo interesujący, nie wyczerpuje problematyki potencjału wykorzystania lapbooków w bibliotece. Co ciekawe, lapbook jest narzędziem stosowanym w Polsce z powodzeniem w praktyce bibliotekarskiej, o czym świadczą wpisy publikowane na stronach internetowych i blogach bibliotek (Ferie z ksiażką.., 2018) (Co to jest lapbook..., 2019) (Konkurs na lapbook, 2019), a równocześnie niemal zupełnie nieobecnym $\mathrm{w}$ piśmiennictwie. Zdiagnozowana luka w literaturze przedmiotu powinna zostać uzupełniona biorąc pod uwagę interesujące konteksty wykorzystania lapbooka jako narzędzia promocji czytelnictwa.

\section{LAPBOOK - CECHY I FUNKCJE}

Lapbook (słowo tłumaczone niekiedy na język polski jako „książka na kolanach") to najogólniej specjalnie przygotowana teczka, często przypominająca wyglądem miniksiążkę, zawierająca elementy tekstu np. ciekawe cytaty, a także rysunki, np. przedstawiające bohaterów książki, trójwymiarowe modele, np. obrazujące opisywane światy czy zagadnienia, oraz ukryte schowki i kieszonki zawierające zabawki, gry czy zagadki relewantne dla omawianego tematu. Jak pisze K. Stącel, lapbook to: „(...) książka tematyczna, która zawiera informacje z różnych źródeł przedstawione w bardzo prosty i atrakcyjny dla dzieci sposób" (Stącel, 2014, s. 24). Głównym celem stosowania lapbooka jest pobudzenie wyobraźni i zaangażowania odbiorcy poprzez twórcze zaaranżowanie zwykłej teczki $\mathrm{w}$ interaktywną przestrzeń rozrywkową i edukacyjną. Zdaniem autorki, lapbook „(...) wyzwala kreatywne myślenie, rozwija wyobraźnię dziecka, inspiruje i pobudza ciekawość, a także uczy zorganizowanej pracy w grupie" (Stącel, 2014, s. 24). Lapbook może być przy tym stosowany w różnych kontekstach - w szkołach jako pomoc dydaktyczna, w bibliotekach jako narzędzie promocji literatury czy w domu jako forma zabawy (Stącel, 2014; Peycheva \& Lazarova, 2018). Istotną zaletą lapbooka jest fakt, że może on być spersonalizowany pod kątem konkretnego odbiorcy lub grupy odbiorców, a sam proces jego wykonania może się stać elementem aktywizującym.

Korzystanie z lapbooka opiera się na idei stopniowego odkrywania ukrytych w nim treści, nawiązując do nielinearnego, interaktywnego przeka$\mathrm{zu}$, co upodabnia to narzędzie do form komunikacji popularnych w środowisku sieciowym i bliskich młodemu odbiorcy. Wśród głównych cech lapbooka można wymienić: tradycyjna, papierową formę, łączenie wielu sposobów przekazu treści, spersonalizowany charakter, interaktywność 
oraz nielinearny charakter przekazu. Do głównych funkcji lapbooka można zaliczyć funkcję informacyjna, edukacyjna, promocyjną i rozrywkowa, choć potencjał lapbooka zależy głównie od kontekstu i zakresu jego wykorzystania.

\section{LAPBOOK A KULTURA DIY}

Współcześnie klienci, użytkownicy i odbiorcy usług, zarówno komercyjnych, jak i niekomercyjnych, odczuwają zmęczenie masowo produkowanymi przedmiotami o małej oryginalności i niskiej jakości. Co za tym idzie, coraz częściej podejmują próby samodzielnego wytwarzania dóbr i usług o spersonalizowanym charakterze. Zachowanie to jest w literaturze przedmiotu nazywane rozwojem kultury DIY (ang. Do It Yourself, pol. Zrób to sam) i dotyczy osób reprezentujących różne grupy demograficzne, przeważanie jednak osób dorosłych odczuwających potrzebę twórczej ekspresji (Wolf \& McQuitty, 2011). W ramach kultury DIY rozwija się m.in. tradycyjne rękodzieło (np. rzeźba, stolarstwo), robótki ręczne (np. na drutach, szydełku), tradycyjna kuchnia (np. samodzielne pieczenie chleba czy robienie przetworów) i wiele innych przejawów działalności twórczej zmierzającej do wytworzenia konkretnego produktu lub usługi na użytek własny lub na potrzeby drobnej działalności gospodarczej.

Jedną z form DIY jest tzw. scrapbooking, a więc utrwalanie wspomnień w formie samodzielnie wykonanej książki-pamiętnika, łączącej elementy tekstu, grafiki i elementów 3D, najczęściej o wysokich walorach estetycznych (Goodsell \& Seiter, 2011). W tym kontekście lapbook, stanowiący spersonalizowaną, samodzielnie wykonaną przez użytkownika teczkę łączącą różne sposoby przekazu treści z elementami o charakterze estetycznym, może być postrzegany jako forma scrapbooka, a tym samym istotny element kultury DIY. Tradycyjna, papierowa forma lapbooka i jego spersonalizowany charakter oraz duża oryginalność dobrze wpisują się w postulaty kultury DIY. Jak zaznaczono wcześniej, uczestnikami kultury DIY są przedstawiciele różnych grup wiekowych i społecznych, można zatem przypuszczać, że choć w literaturze przedmiotu trudno w tej chwili znaleźć opisy tego rodzaju praktyk, lapbook może być z powodzeniem wykorzystywany nie tylko dla celów edukacyjnych i aktywizacyjnych dzieci i młodzieży, ale także osób dorosłych zainteresowanych pracą twórczą. Tworzenie lapbooków może stać się elementem oferty bibliotecznej kierowanej jednocześnie do dzieci i rodziców, którzy mogą wspólnie pracować nad wykonaniem lapbooka na interesujący ich temat. Wspólna praca dzieci i opiekunów na projektem lapbooka może korzystnie wpływać na procesy aktywizacji czytelniczej, przede wszystkim dzieci, ale niewykluczone, że także rodziców. Można także zakładać, że wykorzystanie w bibliotece lap- 
booka, formy nawiązującej do popularnego nurtu kultury DIY, może stać się elementem budowania pozytywnego wizerunku bibliotek jako instytucji podążających za nowymi trendami społecznymi i kulturowymi.

\section{LAPBOOK A PERSONALIZACJA USŁUG BIBLIOTECZNYCH}

Personalizacja jest jedną z kluczowych cech wymienianych $w$ literaturze przedmiotu jako wyróżniająca nowoczesne usługi, w tym także usługi biblioteczne (Wójcik, 2018). Jak zaznaczają Magdalena Ratalewska i Agnieszka Wierzbicka, personalizacja nie jest zjawiskiem nowym, już na początku XXI w. zaczęto dostrzegać potencjał tego rodzaju działań dla zwiększania efektywności działań biznesowych (Ratalewska, Wierzbicka, 2017). Personalizacja jest $\mathrm{w}$ tym kontekście rozumiana jako zapewnienie klientom możliwości dostosowania produktu lub usługi do własnych indywidualnych potrzeb i preferencji, tak w warstwie estetycznej, jak i funkcjonalnej. Klienci, szczególnie ci reprezentujący tzw. pokolenie Z, mają tendencje do postrzegania siebie i swoich potrzeb jako wyjątkowych i niepowtarzalnych, stąd też korzystanie ze standardowych opcji i usług nie jest dla nich satysfakcjonujące (Aniszewska, 2015). Klienci oczekują zatem, że produkty i usługi zostaną dostosowane - przynajmniej w pewnym stopniu - do ich indywidualnych cech, potrzeb, preferencji i zainteresowań. Trendy w zakresie personalizacji usług dotyczą także bibliotek użytkownicy, szczególnie młodsi, przyzwyczajeni do wysokiego stopnia personalizacji usług komercyjnych, oczekują podobnego doświadczenia w bibliotekach (Balke, 2015).

Stosowanie lapbooków może się dla bibliotek stać jedną z wielu form wdrażania idei personalizacji usług. Jak podkreśla K. Stącel, opisując praktyczne aspekty stosowania lapbooków w bibliotece: „w całym przedsięwzięciu bardzo ważne jest, aby pozwolić dzieciom samym zdecydować o poszczególnych etapach pracy: jak zaprojektują okładkę, jaki wybiorą kształt i kolor karteczek, jak ozdobią książkę, jak będzie się otwierała, jakie informacje wpiszą na karteczki, jakie rysunki wykonają (...) (Stącel, 2014, s. 25). Widać więc wyraźnie, że opcje personalizacji stanowią integralną część koncepcji lapbooka. Podejmowane przez dzieci pozornie niewielkie decyzje - wybór tematu lapbooka, papieru, kolorów czy ilustracji - dają im możliwość dostosowania tego narzędzia do własnych potrzeb oraz poczucie satysfakcji i odpowiedzialności za efekt końcowy. W tym kontekście stosowanie lapbooka jako formy aktywizacji czytelniczej o wysokim stopniu personalizacji, może dobrze wpisywać się w obowiązujące na rynku usług trendy. Spersonalizowany charakter lapbooka, dostosowany do wieku, zainteresowań i preferencji estetycznych odbiorcy jest dobrą reprezentacją personalizacji usług $\mathrm{w}$ bibliotece, $\mathrm{w}$ tym przypadku usług informacyjnych czy edukacyjnych. 


\section{LAPBOOK A WZMOCNIENIA HAPTYCZNE}

Technologie haptyczne, to najogólniej grupa nowych technologii bazujących na zmyśle dotyku (Fernandez, 2017). Celem używania wzmocnień haptycznych jest najczęściej zapewnienie komfortu korzystania z produktów i usług, a także budowanie pozytywnego doświadczenia użytkownika. Wzmocnienia haptyczne są masowo stosowane w projektowaniu usług elektronicznych. Przykładem może być choćby odczuwanie przez użytkowników urządzeń mobilnych wrażenia nacisku na wypukły element (np. guzik) przy używaniu płaskich ekranów dotykowych czy wibracje urządzenia sygnalizujące wykonanie przez użytkownika określonej akcji (Tiwari, 2016). Wzmocnienia haptyczne są także stosowane w innych, niezwiązanych ze środowiskiem elektronicznym, kontekstach, np. do kontroli ruchu pojazdów (np. kierujący pojazdem odczuwa wibracje przy najechaniu na linię oddzielającą pasy drogowe) czy oznaczania przejść dla pieszych (np. wypukłe elementy nawierzchni dla osób niewidomych).

Koncepcja wzmocnień haptycznych jest znana w naukach pedagogicznych od dawna. Opiera się na założeniu, że uzupełnienie komunikatów wizualnych, czy werbalnych o elementy bazujące na zmyśle dotyku przynosi korzyści edukacyjne. Przykładem takiego podejścia może być choćby stosowanie trójwymiarowych pomocy edukacyjnych, np. brył, zabawek edukacyjnych, modeli, wizualizacji 3D itp. do nauki przedmiotów wymagających abstrakcyjnego myślenia, np. geometrii czy fizyki. Stosowanie wzmocnień haptycznych jest popularne szczególnie, choć nie tylko, w edukacji osób - zarówno dzieci, jak i dorosłych - o specjalnych potrzebach edukacyjnych. U osób z niepełnosprawnością sensoryczną intelektualną czy emocjonalną wykorzystanie wzmocnień haptycznych pomaga w prawidłowej realizacji procesów edukacyjnych (Im, Yun \& Kim, 2017).

Wzmocnienia haptyczne mogą być także wykorzystywane w działaniach bibliotek, szczególnie w kontekście realizacji usług i oferty edukacyjnej (Wójcik, 2019). Stosowanie elementów haptycznych w projektowaniu zasobów elektronicznych bibliotek, np. interaktywnych tablic informacyjnych, jak również stosowanie trójwymiarowych, dotykowych pomocy dydaktycznych może podnieść jakość ogólnego doświadczenia klienta w bibliotece. Używanie trójwymiarowej, opartej na bodźcach dotykowych formy aktywizacji czytelniczej jaką jest lapbook, dobrze wpisuje się założenia wzmocnień haptycznych w edukacji i może przynieść korzyści w projektowaniu lekcji bibliotecznych i warsztatów, jak również w organizacji promocji książki i aktywizacji czytelniczej dzieci.

\section{LAPBOOK A POWRÓT DO KULTURY ANALOGOWEJ}

Jednym z interesujących zjawisk społecznych jest powrót mody na wybrane elementy kultury analogowej, np. gry planszowe, płyty gramo- 
fonowe czy aparaty typu polaroid. Na rynku gospodarczym opisuje się w tym kontekście zjawisko tzw. retro-innowacji, sytuacji, w której nowoczesne marki celowo stylizują swoje produkty lub usługi w sposób nawiązujący nostalgicznie do minionych epok. Jak piszą Magdalena Grębosz i Jean-Marc Pointet: „Na rynek powracają marki od lat nieobecne, znane z przeszłości ( $z$ w. rzeczywiste marki retro), istniejące marki są repozycjonowane zgodnie $\mathrm{z}$ koncepcją marketingu retro, wprowadzane są nowe marki retro, a odwołania do stylu retro są coraz częściej wykorzystywane podczas rozwoju koncepcji produktu i opakowania oraz w marketingowych kampaniach komunikacyjnych" (Grębosz, Pointet, 2016, s. 53). Łączy się to ze zjawiskiem rozwoju kultury unplugged, czyli okazjonalnym odczuwaniem przez osoby aktywnie korzystające z nowych technologii zmęczenia środowiskiem elektronicznym i potrzebą odłączenia się, najczęściej na krótki czas, od nowoczesnych narzędzi. Trend ten jest zauważany także w bibliotekach. American Library Association wymienia tworzenie $\mathrm{w}$ bibliotece unplugged zones, stref wolnych od technologii, jako jeden z trendów kluczowych dla przyszłości bibliotek (ALA). Unplugged zones pozwalają użytkownikom odpocząć od napływu bodźców płynących z urządzeń elektronicznych, zregenerować się, uporządkować myśli i poświęcić czas spokojnej lekturze czy refleksji. Warto zaznaczyć, że wspieranie tendencji unplugged nie oznacza negowania osiągnięć nowych technologii, a jedynie pokazuje potrzebę zachowania równowagi między nowoczesnością a tradycją. W tym kontekście prowadzenie procesów aktywizacji czytelniczej i promocji literatury przy użyciu tradycyjnego, nieelektronicznego narzędzia, jakim jest lapbook wydaje się ciekawym rozwiązaniem, dobrze wpisującym się w trendy społeczne. Wykonanie lapbooka wiąże się z pracą koncepcyjną i manualna, nie wymaga używania urządzeń elektronicznych, choć także ich nie wyklucza np. jako źródła informacji. Lapbook może stać się nie tylko narzędziem promującym książkę, ale także elementem edukacji dzieci w zakresie odpowiedzialnego i zbalansowanego korzystania z zasobów sieciowych, pokazując alternatywne sposoby spędzania wolnego czasu.

\section{LAPBOOK JAKO NARZĘDZIE AKTYWIZACJI CZYTELNICZEJ}

W kontekście działań bibliotecznych lapbook jest stosowany jako narzędzie promocji literatury oraz forma aktywizacji czytelniczej kierowana najczęściej, choć nie tylko, do dzieci i młodzieży. Nie tylko w bibliotekach zagranicznych, ale także w polskich można wskazać przykłady kreatywnego wykorzystania lapbooków, szczególnie w bibliotekach szkolnych i pedagogicznych. Filia Publicznej Biblioteki Pedagogicznej w Myszkowie zorganizowała na przykład zajęcia promujące edukację czytelniczą i medialna, podczas których uczestnicy - uczniowie szkół podstawowych 
- tworzyli lapbooki na tematy zgodne z ich własnymi zainteresowaniami, zarówno tymi czytelniczymi, jak i innymi (Loch, 2016). W niektórych klasach tworzono także lapbooki związane z konkretna, omawianą książka, np. Przygody Mikołajka czy W pustyni i w puszczy. Relacjonując przebieg zajęć, Beata Loch zaznacza, że tworzenie lapbooków stanowi bodziec do twórczej pracy z książka, pozwala dzieciom wykorzystywać ich indywidualne zdolności, współpracować w grupie (np. wymieniając się materiałami) oraz stanowi źródło radości i pozwala przyjemnie spędzić czas w bibliotece (Loch, 2016). Uczniowie Szkoły Podstawowej w Kunowie brali udział w warsztatach tworzenia lapbooków na podstawie bajki o Czerwonym Kapturku. Warsztaty zostały dofinansowane ze środków ministra kultury i dziedzictwa narodowego (Bajeczny lapbook, 2019). Podobne działania podjęto także w Bibliotece Pedagogicznej w Swarzędzu. W trakcie dwudniowych warsztatów uczniowie mieli możliwość obejrzenia gotowych lapbooków dotyczących bohaterów literackich, książek i autorów, a następnie samodzielnie sporządzali lapbooki. Gotowe prace można było oglądać w bibliotece, a najlepsze zostały nagrodzone (Ferie z książką..., 2018). Konkurs na lapbook zorganizowała także biblioteka Zespołu Placówek Oświatowych w Czechowicach-Dziedzicach. Uczestnicy konkursu „Radość czytania, radość tworzenia” przygotowywali lapbooki dotyczące ulubionych książek (Wystawa lapbooków, 2016). Zespół szkolno-przedszkolny w Bachowicach zorganizował z kolei konkurs „Mój lapbook na temat: Miś w książkach i wierszach" dla uczniów edukacji wczesnoszkolnej (Wyniki konkursu, 2019).

Przytoczone przykłady pokazuja, że lapbook jest z powodzeniem wykorzystywany w wielu polskich bibliotekach jako narzędzie aktywizacji czytelniczej, element promocji książki, a także pomoc dydaktyczna. Prosta do wykonania, a jednocześnie atrakcyjna, interaktywna i spersonalizowana forma lapbooka decyduje o jego dużej użyteczności w prowadzeniu działań aktywizujących, czytelniczych i edukacyjnych.

\section{WNIOSKI}

Lapbook jest narzędziem z powodzeniem stosowanym w praktyce bibliotekarskiej w kontekście promowania literatury i aktywizacji czytelniczej. Przystępna forma lapbooka, nieduży koszt jego wykonania oraz spersonalizowany i interaktywny charakter sprawiaja że może być on postrzegany jako narzędzie przydatne w pracy bibliotekarza, szczególnie w kontekście pracy z dziećmi. Mimo stosunkowo dużej popularności lapbooków w działaniach praktycznych, brakuje jednak omówienia tego zjawiska od strony teoretycznej, w piśmiennictwie naukowym. Jest to temat poruszany rzadko zarówno w literaturze polskiej, jak i zagranicznej. Wydaje się, że jest to zjawisko na tyle interesujące, że powinno pojawiać się 
częściej jako przedmiot rozważań teoretycznych. Warto byłoby również przeprowadzić badania empiryczne pokazujące dokładniej skalę i sposoby wykorzystania lapbooków w polskich bibliotekach.

\section{BIBLIOGRAFIA}

ALA. Center for future trends - unplugged [online], [dostęp: 06.01.2020]. Dostępny w WWW: <http://www.ala.org/tools/future/trends/unplugged>.

Aniszewska, Grażyna (2015). Zmiany pokoleniowe a decyzje i wybory konsumenckie. Marketing i rynek, 22(1), s. 2-7.

Badanie Młodzi cyfrowi - najważniejsze wyniki oraz pełen raport już dostępne! (2019) [online], [dostęp: 10.02.2020]. Dostępny w WWW: <dbamomojzasieg.com>.

Bajeczny lapbook (2019) [online] [dostęp: 13.01.2020]. Dostępny w WWW: <www. biblioteka.gostyn.pl>.

Balke, W. (2015). University libraries - between service providers and reseach institutions [online], [dostęp: 10.01.2020]. Dostępny w WWW: <https://docs.lib.purdue.edu/cgi/viewcontent.cgi?article=2078\&context=iatul>.

Co to jest lapbook? I jak go wykorzystać w bibliotece (2019) [online], [dostęp: 23.01. 2020]. Dostępny w WWW: <wWw.biblioteka.klodzko.pl>.

Ferie z ksiażka - lapbook (2018) [online], [dostęp: 10.01.2020]. Dostępny w WWW: $<$ www.swarzedz.pbp.poznan.pl>.

Fernandez, Peter (2017). Through the looking glass: envisioning new library technologies an experience you can feel: haptic technology, Library Hi Tech News, Vol. 34, Issue 3, pp. 12-15.

Gmiterek, Grzegorz; Kotuła, Sebastian (2017). Aplikacje mobilne nie tylko w bibliotece. Warszawa: Wydaw. SBP.

Goodsell, Todd; Seiter, Liann (2011). Scrapbooking: Family capital and the construction of family discourse. Journal of Contemporary Ethnography, Vol. 40.3, pp. 318-341.

Grębosz, Magdalena; Pointet, Jean-Marc (2016). Paradoks „retro-innowacji” w zarządzaniu marką. Nauki o Zarzadzaniu, nr 1 (26), s. 52-62.

Instytut Badawczy IPC (2017). Korzystanie z urządzeń elektronicznych oraz Internetu przez dzieci i młodzież: raport z badań ilościowych wśród uczniów i nauczycieli z Krakowa [online], [dostęp: 06.02.2020]. Dostępny w WWW: <www.mcpu.krakow.pl>.

Im, Tami; Yun, Im-ho; Kim, Sang-Youn (2017). Holistic Haptic Education Platform for Developmental Disorder Children. International Journal of Applied Engineering Research, Vol. 12, Issue 17, pp. 6615-6622.

Konkurs na lapbook (2019) [online], [dostęp: 10.01.2020]. Dostępny w WWW: $<$ www.bpsuwalki.pl>.

Loch, Beata (2016). Lapbook co to takiego? [online], [dostęp: 11.01.2020]. Dostępny w WWW: <www.biblioteka.womczestochowa.edu.pl>.

McGrew Jaime, Catherine; Fuller, Deirdre (2013). Lapbooking Made Easy. Madison: Creative Learing Connection.

Peycheva, Yordanka; Lazarova, Snezhana (2018). The lapbook as a didactic tool to implement integrated training in natural science and technology and entre- 
preneurship at primary school level. Knowledge International Journal, Vol. 28.3, pp. 959-963.

Ratalewska, Magdalena; Wierzbicka, Agnieszka (2017). Personalizacja w Internecie - innowacyjna strategia na rynku MŚP. Przedsiębiorczość i zarządzanie, Tom XVIII, Zeszyt 12, s. 319-333.

Stącel, Katarzyna (2014). Lapbook w bibliotece szkolnej. Warsztaty artystyczne. Biblioteka w szkole, $\mathrm{nr}$ 9, s. 24-25.

Tiwari, Ankita (2016). A review on haptic science technology and its applications. In: Proceeding of International Conference on Emerging Technologies. Engineering, Biomedical, Management and Science. Singapore: Springer, pp. 78-83.

Wolf, Marco; McQuitty, Shaun (2011). Understanding the do-it-yourself consumer: DIY motivations and outcomes. AMS review, Vol. 1.3-4, pp. 154-170.

Wójcik, Magdalena (2018). Rozszerzona rzeczywistość w ustugach informacyjnych bibliotek. Kraków: Wydaw. Uniwersytetu Jagiellońskiego.

Wójcik, Magdalena (2019). Haptic technology - potential for library services. Library Hi Tech, Vol. 37, No. 4, pp. 883-893.

Wystawa lapbooków (2016) [online], [dostęp: 05.02.2020]. Dostępny w WWW: $<$ http://mbpczechowice.civ.pl/?p=836>.

Artykut w wersji poprawionej wptyną do Redakcji 21 września 2020 r.

MAGDALENA WÓJCIK

Institute of Information Studies

Jagiellonian University

e-mail: magda.wojcik@uj.edu.pl

ORCID: 0000-0001-5059-858X

\section{LAPBOOK AS A NEW MARKETING TOOL FOR CHILDREN'S BOOKS}

KEYWORDS: Libraries. Readership. Innovations. Lapbook. Book marketing

ABSTRACT: Thesis/Objective - The author discusses lapbooks as a marketing tool for children's books. The aim of the article is to define the potential of this form for strengthening the processes of readers' activation. Research method The analysis and critique of the literature was used. The current state of research on lapbooks in the library context was defined based on the results of searches run through the OPAC of the National Library of Poland, WorldCat global union catalog, LISTA database and selected multidisciplinary databases searched via Google Scholar. The materials analyzed were in Polish and English, published in the years 2015-2019. Results - The results of the analysis show that the topic of lapbooks is rare in LIS literature. Conclusions - Lapbooks are promising library tools for book marketing, however the phenomenon has not been widely discussed in the literature of the field so far. 